\title{
FAKTOR-FAKTOR YANG BERHUBUNGAN DENGAN PENERAPAN PERILAKU HIDUP BERSIH DAN SEHAT (PHBS) RUMAH TANGGA DI PULAU LANCANG KELURAHAN PULAU PARI KECAMATAN KEPULAUAN SERIBU SELATAN
}

\author{
Nursa'adah' ${ }^{1)}$, Ajeng Tias Endarti ${ }^{2)}$ \\ Program Studi S1 Kesehatan Masyarakat Universitas MH. Thamrin \\ Program Studi S2 Kesehatan Masyarakat Universitas MH.Thamrin \\ Dadanursaadah@gmail.com
}

\begin{abstract}
ABSTRAK
Perilaku Hidup Bersih dan Sehat (PHBS) Tatanan Rumah Tangga adalah upaya untuk memeberdayakan anggota rumah tangga agar sadar, mau dan mampu melakukan PHBS untuk memelihara dan meningkatkan kesehatannya, mencegah resiko terjadinya penyakit dan melindungi diri dari ancaman penyakit serta berperan aktif dalam gerakan kesehatan. Masyarakat sebagai salah satu indicator terciptanya kota sehat. Untuk mendapatkan gambaran pelaksanaan PHBS masyarakat pada tatanan rumah tangga di Pulau Lancang, Kelurahan Pulau Pari Kecamatan, Kepulauan Seribu Selatan. Metode Studi cross sectional dilaksanakan pada seluruh populasi penelitian yang tinggal di Pulau Lancang Kelurahan Pulau Pari. Populasi dalam penelitian ini adalah 923 KK dengan besar sampel $70 \mathrm{KK}$ terpilih secara proposional melalui teknik random sampling. Hasil yangh didapat dari Rumah Tangga (RT) yang menerapkan PHBS sebanyak 20 responden $(28,6 \%)$, dan yang tidak menerapkan PHBS sebanyak 50 responden $(71,4 \%)$. Tidak adanya hubungan antara variabel dependen dan variabel independen. Kesimpulan dan Saran: Disarankan pada Dinas Kesehatan Kepulauan Seribu, Puskesmas dan Kelurahan Pulau Pari untuk meningkatkan dan mensosialisasikan tentang PHBS kepada masyarakat untuk memperbaiki kesehatan masyarakat.
\end{abstract}

Kata Kunci: PHBS, Pulau Seribu

\section{PENDAHULUAN}

Perilaku Hidup Bersih dan Sehat (PHBS) di rumah tangga adalah upaya untuk memberdayakan anggota rumah tangga agar mengetahui, mau dan mampu mempraktikkan perilaku hidup bersih dan sehat serta berperan aktif dalam gerakan kesehatan di masyarakat. Ada beberapa indikator yang dipakai sebagai ukuran untuk menilai PHBS rumah tangga yaitu persalinan ditolong oleh tenaga kesehatan, memberi ASI ekslusif, menimbang balita setiap bulan, menggunakan air bersih, mencuci tangan dengan air bersih dan sabun, menggunakan jamban sehat, memberantas jentik di rumah sekali seminggu, makan buah dan sayur setiap hari, melakukan aktivitas fisik setiap hari, dan tidak merokok di dalam rumah.

Menurut WHO pada data terakhir tahun 2011, setiap tahunnya sekitar 2,2 juta orang di negara-negara berkembang terutama anak-anak meninggal dunia akibat berbagai penyakit yang disebabkan oleh kurangya air minum yang aman, sanitasi dan hygiene yang buruk. Terdapat bukti bahwa pelayanan sanitasi yang memadai, persediaan air yang aman, sistem pembuangan sampah serta pendidikan hygiene dapat menekan angka kematian akibat diare sampai $65 \%$, serta penyakit-penyakit lainnya sebanyak 26\%. Berdasarkan data diatas dapat dikatan bahwa peran PHBS dalam dasar ilmu kesehatan sangat berperan penting dalam menanggulangi penyakit-penyakit yang dapat timbul dikemudian hari oleh karnanya peran pemerintah, petugas-petugas kesehatan dan masyarakat untuk lebih berperan dan proaktif dalam mengimplementasikan dan melaksanankan strategi PHBS di berbagai tatanan rumah 
tangga, sekolah, tempat kerja, sarana kesehatan dan tempat-tempat umum, untuk kesehatan masyarakat yang lebih sehat.

Berdasarkan hasil Riskesdas 2013 proporsi nasional Rumah tangga dengan PHBS baik adalah 32,3\%. Terdapat 20 Propinsi yang masih memiliki Rumah Tangga dengan PHBS baik dibawah proporsi nasional. Proporsi tertinggi pada DKI Jakarta $(56,8 \%)$ dan terendah pada Papua (16,4\%). Terdapat 20 dari 33 provinsi yang masih memiliki rumah tangga PHBS baik di bawah proporsi nasional. Proporsi nasional rumah tangga PHBS pada tahun 2007 adalah sebesar 38,7\%.Proporsi Rumah Tangga melakukan Perilaku Hidup Bersih dan Sehat (PHBS) yaitu sumber air bersih baik (82,2\%), cuci tangan dengan benar (47,2\%), BAB di jamban $(81,9 \%)$.

Berdasarkan data Puskesmas di masing wilayah Kepulauan Seribu, presentasi PHBS belum maksimal secara menyeluruh di tatanan rumah tangga, khususnya di wilayah kecamatan Kepulauan Seribu Utara. Dimana Pulau Harapan 75\%, Pulau Kelapa 60\% dan Pulau Panggang 48\%. Sedangkan untuk Kecamatan Kepulauan Seribu Selatan sudah dalam kondisi baik, dimana Pulau Untung Jawa 82\%, Pulau Pari 80\% dan Pulau Tidung 80\%.

Berdasarkan keterangan data diatas peneliti tertarik, oleh karena itu peneliti ingin meneliti tentang Faktor-faktor Yang Berhubungan Dengan Penerapan Perilaku Hidup Bersih dan Sehat (PHBS) Rumah Tangga di Pulau Lancang Kelurahan Pulau Pari Kecamatan Kepulauan Seribu Selatan Tahun 2018.

\section{METODE}

Penelitian ini menggunakan metode penelitian studi deskriftif Cross-Sectional untuk mengetahui penerapan perilaku hidup bersih dan sehat rumah tangga. Penelitian ini dilaksanakan di Pulau Lancang Kelurahan Pulau Pari Kecamatan Kepulauan Seribu Selatan. Populasi dalam penelitian ini adalah 923 Kartu Keluarga. Dalam penelitian ini sampel yang dihitung menggunakan rumus Lameshow dengan teknik random sampling. Intrumen pada penelitian ini menggunakan kuesioner, analisis bivariat penelitian ini akan menghubungkan variabel dependen dengan variabel independen dengan menggunakan uji statistic chi-square dengan $\alpha<0,05$.

\section{HASIL DAN PEMBAHASAN}

\section{Hasil Univariat}

Gambaran Faktor-faktor Yang Berhubngan Dengan Penerapan Perilaku Hidup Bersih dan Sehat (PHBS) Rumah di Pulau Lancang

Tabel 1

Distribusi Frekuensi Perilaku Hidup Bersih dan Sehat (PHBS) Rumah Tangga di Pulau Lancang.

\begin{tabular}{ccc}
\hline $\begin{array}{c}\text { PHBS Rumah } \\
\text { Tangga }\end{array}$ & $\mathbf{N}$ & $\mathbf{\%}$ \\
\hline Tidak Menerapkan & 50 & 71,4 \\
\hline Menerapkan & 20 & 28,6 \\
\hline Total & $\mathbf{7 0}$ & $\mathbf{1 0 0 , 0}$ \\
\hline
\end{tabular}

Tabel 1 diatas dapat dilihat bahwa dari 70 responden yang diteliti, menunjukkan bahwa responden yang menerapkan PHBS sebanyak 20 responden $(28,6 \%)$, sedangkan yang tidak menerapkan sebanyak 50 responden $(71,4 \%)$. 


\section{Tabel 2}

Distribusi Responden Pada Perilaku Hidup Bersih dan Sehat (PHBS) Rumah Tangga di Pulau Lancang

\begin{tabular}{|c|c|c|}
\hline Umur & $\mathbf{N}$ & $\%$ \\
\hline$\geq 30$ tahun & 47 & 67,1 \\
\hline$\leq 30$ tahun & 23 & 32,9 \\
\hline \multicolumn{3}{|l|}{ Total } \\
\hline \multicolumn{3}{|l|}{ Pendidikan } \\
\hline Rendah & 40 & 57,1 \\
\hline Tinggi & 30 & 42,9 \\
\hline \multicolumn{3}{|l|}{ Total } \\
\hline \multicolumn{3}{|l|}{ Pengetahuan } \\
\hline Rendah & 45 & 64,3 \\
\hline Tinggi & 25 & 35,7 \\
\hline \multicolumn{3}{|l|}{ Total } \\
\hline \multicolumn{3}{|l|}{ Sikap } \\
\hline Kurang baik & 36 & 51,4 \\
\hline Baik & 34 & 48,6 \\
\hline \multicolumn{3}{|l|}{ Total } \\
\hline \multicolumn{3}{|c|}{ Lingkungan Fisik } \\
\hline Kurang baik & 19 & 27,1 \\
\hline Baik & 51 & 72,9 \\
\hline Total & 70 & 100,0 \\
\hline
\end{tabular}

Tabel 2 diatas dapat dilihat bahwa dari 70 responden yang diteliti, menunjukkan bahwa responden yang umur nya $\geq 30$ tahun sebanyak 47 responden $(67,1 \%)$, dan umur $\leq 30$ tahun sebanyak 23 responden $(32,9 \%)$. Pendidikan rendah sebanyak 40 responden $(57,1 \%)$, dan pendidikan tinggi sebanyak 30 responden $(42,9 \%)$. Pengetahuan rendah sebanyak 45 responden (64,3\%), dan pengetahuan tinggi 25 responden (35,7\%). Sikap kurang baik sebanyak 34 responden $(48,6 \%)$, dan sikap baik sebanyak 36 responden (51,4\%). Lingkungan fisik kurang baik sebanyak 19 responden $(27,1 \%)$, dan sikap baik sebanyak 51 responden $(72,9 \%)$.

\section{Hasil Bivariat}

Analisis bivariat dilakukan untuk mengetahui adanya factor-faktor yang berhubungan dengan penerapan PHBS pada tatanan rumah tangga, dengan menghubungkan secara statistic variabel yaitu variebel dependen (perilaku hidup bersih dan sehat) dan variabel independen (umur, pendidikan, pengentahuan, sikap, ketersediaan sarana).

Uji statistic yang digunakan adalah uji Chi-Square, dimana uji Chi-Square tersebut digunakan untuk menguji perbedaan proporsi atau presentase antara beberapa kelompok data. 
Tabel 3

Hubungan antara Umur, Pendidikan, Pengetahuan, Sikap dan Ketersediaan Sarana Dengan Perilaku Hidup Bersih dan Sehat (PHBS) Rumah Tangga di Pulau Lancang Tahun 2018

\begin{tabular}{|c|c|c|c|c|c|c|c|c|c|c|}
\hline \multirow[t]{2}{*}{ Variabel } & \multirow{2}{*}{$\begin{array}{c}\text { PHBS } \\
\text { Rumah } \\
\text { Tangga }\end{array}$} & \multicolumn{2}{|c|}{$\begin{array}{c}\text { Tidak } \\
\text { Menerapkan }\end{array}$} & \multicolumn{2}{|c|}{ Menerapkan } & \multicolumn{2}{|c|}{ Total } & \multirow[t]{2}{*}{$\begin{array}{c}P- \\
\text { Value }\end{array}$} & \multirow[t]{2}{*}{$\mathbf{P R}$} & \multirow[t]{2}{*}{$\begin{array}{c}\text { CI } \\
95 \%\end{array}$} \\
\hline & & $\bar{f}$ & $\%$ & $\mathrm{f}$ & $\%$ & $\mathrm{f}$ & $\%$ & & & \\
\hline \multirow[b]{2}{*}{ Umur } & $\begin{array}{l}\geq 30 \\
\text { Tahun }\end{array}$ & 35 & 74,5 & 12 & 65,2 & 47 & 100 & \multirow[b]{2}{*}{1,000} & \multirow[b]{2}{*}{1,000} & \\
\hline & $\begin{array}{l}\leq 30 \\
\text { Tahun }\end{array}$ & 15 & 16,4 & 8 & 6,6 & 23 & 100 & & & $\begin{array}{l}0,250- \\
3,998\end{array}$ \\
\hline \multirow[t]{2}{*}{ Pendidikan } & Rendah & 27 & 28,6 & 13 & 11,4 & 40 & 100 & \multirow{2}{*}{0,318} & \multirow{2}{*}{0,449} & 0,093- \\
\hline & Tinggi & 23 & 21,4 & 7 & 8,6 & 30 & 100 & & & 2,16 \\
\hline \multirow[t]{2}{*}{ Pengetahuan } & Rendah & 39 & 32,1 & 6 & 12,9 & 45 & 100 & \multirow{2}{*}{0,118} & \multirow{2}{*}{3,500} & 0,727- \\
\hline & Tinggi & 11 & 17,9 & 14 & 7,1 & 25 & 100 & & & 16,848 \\
\hline \multirow[t]{2}{*}{ Sikap } & $\begin{array}{c}\text { Kurang } \\
\text { Baik }\end{array}$ & 31 & 24,3 & 3 & 9,7 & 34 & 100 & \multirow[t]{2}{*}{0,125} & \multirow[t]{2}{*}{5,091} & \\
\hline & Baik & 19 & 25,7 & 17 & 10,3 & 36 & 100 & & & \\
\hline \multirow{2}{*}{$\begin{array}{l}\text { Ketersediaan } \\
\text { Sarana }\end{array}$} & Kurang Memadai & 19 & 13,6 & 7 & 7,4 & 26 & 100 & \multirow[b]{2}{*}{0,265} & \multirow[b]{2}{*}{$\mathbf{0 , 0 3 0}$} & \\
\hline & Memadai & 31 & 36,4 & 13 & 12,6 & 44 & 100 & & & 14,280 \\
\hline
\end{tabular}


Berdasarkan tabel di atas, hasil analisi hubungan antara umur, pedidikan, pengetahuan, sikap dan ketersediaan sarana prasarana dengan perilaku hidup bersih dan sehat (PHBS) Rumah Tangga diperoleh, bahwa 47 responden dan 40 responden yang masuk dalam kategori umur $\geq 30$ tahun, pendidikan rendah pengetahuan yaitu 35 responden (74,5\%) dan 27 responden (28,6\%) tidak menerapkan perilaku hidup bersih dan sehat (PHBS) Rumah Tangga, dan yang menerapkan 12 responden $(65,2 \%)$ dan 13 responden $(11,4 \%)$ pendidikan rendah. Sedangkan 23 responden dan 30 responden yang masuk dalam kategori umur $\leq 30$ tahun dan pendidikan tinggi yaitu 15 responden $(16,4 \%)$ dan 23 responden $(21,4 \%)$ tidak menerapkan perilaku hidup bersih dan sehat (PHBS) Rumah Tangga, dan yang menerapkan 8 reponden $(6,6 \%)$ dan 7 responden $(8,6 \%)$. Selain itu, hasil uji Chi-Square diperoleh nilai sebesar $P=1,000$ dan $P=0,318$ ( $>>0,05$ ) yang berarti tidak ada hubungan yang signifikan antara umur dan pendidikan dengan penerapan perilaku hidup bersih dan sehat (PHBS) Rumah Tangga.

Hasil analisis hubungan antara pengetahuan, sikap, dan ketersediaan sarana prasarana dengan perilaku hidup bersih dan sehat (PHBS) Rumah Tangga diperoleh, bahwa pengetahuan 45 responden, sikap 34 responden dan ketersediaan sarana 19 responden dalam kategori pengetahuan rendah, sikap rendah dan ketersediaan saran kurang memadai yaitu pengetahuan 39 responden (32,1\%), sikap 31 responden $(24,3 \%)$ dan ketersediaan sarana 19 responden (13,6\%) tidak menerapkan perilaku hidup bersih dan sehat (PHBS) Rumah Tangga, dan yang menerapkan pengetahuan 6 responden (12,9\%) masuk dalam kategori pengetahuan tinggi, sikap 3 responden $(9,7 \%)$ dan $7(7,4 \%)$ masuk dalam kategori sikap dan ketersediaan sarana memadai. Sedangkan 25 responden yang masuk dalam kategori pengetahuan tinggi sebanyak 11 responden (17,9\%), 36 responden yang masuk dalam kategori sikap baik sebanyak 19 responden $(25,7 \%)$ dan 51 responden yang masuk dalam kategori ketersediaan sarana memadai sebanyak 31 responden $(36,4 \%)$ tidak menerapkan perilaku hidup bersih dan sehat (PHBS) Rumah Tangga, dan yang menerapkan 14 responden (7,1\%) pengetahuan tinggi, 17 responden (10,3\%) sikap baik dan 13 responden $(12,6 \%)$ ketersediaan sarana memadai. Selain itu, hasil uji Chi-Square diperoleh nilai sebesar $P=0,118$ pengetahuan, $P=0,125$ sikap dan $P=0,265$ ketersediaan sarana $(\mathrm{p} \leq 0,05)$ yang berarti tidak adanya hubungan yang signifikan antara pengetahuan dan sikap dengan penerapan perilaku hidup bersih dan sehat (PHBS) rumah tangga, dan tidak adanya hubungan yang signifikan antara ketersediaan sarana prasaran dengan penerapan perilaku hidup bersih.

\section{PEMBAHASAN}

Perilaku Hidup Bersih dan Sehat (PHBS) adalah kesimpulan perilaku yang di praktekan atas dasar kesadaran sebagai hasil pembelajaran, yang menjadikan seseorang keluarga, kelompok atau masyarakat mampu menolong dirinya sendiri (mandiri) dibidang kesehatan dan berperan aktif dalam mewujudkan kesehatan masyarakat (KemenKes RI, 2011).

PHBS di Rumah Tangga adalah upaya untuk memberdayakan anggota rumah tangga agar tahu, mau dan mampu melaksanakan perilaku hidup bersih dan sehat serta berperan aktif dalam gerakan kesehatan di masyarakat. PHBS di Rumah Tangga dilakukan untuk mencapai Rumah Tangga Sehat. Rumah tangga sehat berarti mampu menjaga, meningkatkan, dan melindungi kesehatan setiap anggota rumah tangga dari gangguan ancaman penyakit dan lingkungan yang kurang kondusif untuk hidup sehat (Depkes RI, 2007). PHBS merupakan salah satu strategi yang 
dapat ditempuh untuk menghasilkan kemandirian di bidang kesehatan baik pada masyarakat maupun pada keluarga, artinya harus ada komunikasi antara kader dengan keluarga/masyarakat untuk memberikan informasi dan melakukan pendidikan kesehatan (Depkes RI, 2007).

Dapat disimpulkan bahwa PHBS Rumah Tangga ditujukan agar anggota rumah tangga lebih mandiri dalam menjaga kesehatannya agar terhindar dari penyakit.

Berdasarkan hasil Riskesdas 2013 proporsi nasional Rumah tangga dengan PHBS baik adalah 32,3\%. Terdapat 20 Propinsi yang masih memiliki Rumah Tangga dengan PHBS baik dibawah proporsi nasional. Proporsi tertinggi pada DKI Jakarta $(56,8 \%)$ dan terendah pada Papua (16,4\%). Terdapat 20 dari 33 provinsi yang masih memiliki rumah tangga PHBS baik di bawah proporsi nasional. Proporsi nasional rumah tangga PHBS pada tahun 2007 adalah sebesar 38,7\%.Proporsi Rumah Tangga melakukan Perilaku Hidup Bersih dan Sehat (PHBS) yaitu sumber air bersih baik (82,2\%), cuci tangan dengan benar (47,2\%), BAB di jamban (81,9\%).

Berdasarkan data Puskesmas di masing wilayah Kepulauan Seribu, presentasi PHBS belum maksimal secara menyeluruh di tatanan rumah tangga, khususnya di wilayah kecamatan Kepulauan Seribu Utara. Dimana Pulau Harapan 75\%, Pulau Kelapa 60\% dan Pulau Panggang 48\%. Sedangkan untuk Kecamatan Kepulauan Seribu Selatan sudah dalam kondisi baik, dimana Pulau Untung Jawa 82\%, Pulau Pari 80\% dan Pulau Tidung 80\%.

Berdasarkan penelitian yang dilakukan peneliti di Pulau Lancang Kelurahan Pulau Pari Kecamatan Kepulauan Seribu Selatan Tahun 2018 diperoleh hasil responden yang menerapkan PHBS adalah sebanyak 20 responden $(28,6 \%)$.

Hasil tersebut menunjukkan angka yang lebih rendah dibandingkan penelitian serupa yang dilakukan oleh Nita Novianti (2014) tentang "Faktor-faktor Yang Berhubungan Dengan Penerapan Perilaku Hidup Bersih dan Sehat (PHBS) Rumah Tangga di Kelurahan Jatiasih, Kota Bekasi', yang memperoleh hasil 62,1\% responden yang berPHBS baik dari 87 responden. Namun hasil penelitian ini juga menunjukkan angka lebih tinggi dibandingkan penelitian yang dilakukan oleh Suryani (2013) tentang 'Hubungan Pengetahuan dan Sikap Ibu Rumah Tangg Terhadap Perilaku Hidup Bersih dan Sehat di Kelurahan Payo Selincah', yang memperoleh hasil 54\% resonden yang ber-PHBS baik.

PHBS merupakan salah satu upaya pencegahan berbagai macam penyakit, baik penyakit menular maupun penyakit tidak menular. PHBS rumah tangga memiliki 10 indikator yang terdiri dari 3 indikator Kesehatan Ibu dan Anak (KIA) yaitu persalinan ditolong tenaga kesehatan, member ASI Eksklusif, dan menimbang bayi/balita di Posyandu, 4 indikator berbasis perilaku dan lingkungan yaitu menggunaka ir bersih, jamban sehat, cuci tanga dengan air dan sabun serta memberantas sarang nyamuk, terakhir 3 indikator gaya hidup sehat yang meliputi makan buah dan sayur setiap hari, melakukan aktfitas fisik dan tidak merokok didalam rumah. Masing-masing indicator berperan dalam mencegah beberapa maslah kesehatan seperti indicator KIA dapat mencegah kasus gizi buruk pada balita, menurunkan angka kematian ibu maupun bayi serta mencegah bayi terkena penyakit seperti diare, ISPA dan lain sebagainya. Indicator berbasis lingkungan dapat berkontribusi dalam mencegah berbagai penyakit menular seperti 
Diare, ISPA, DBD, Malaria, Kusta dan lain sebagainya. Sedangkan indicator gaya hidup sehat diharapkan dapat mencegah terjadinya sehat (PHBS) rumah tangga

penyakit tidak menular (PTM). Mencegah selalu akan jauh lebih baik darpada mengobati, oleh karena itu penerapan PHBS rumah tangga sangat wajib untuk ditingkatkan.

\section{Umur}

Dari hasil penelitian di Pulau Lancang tentang Perilaku Hidup Bersih dan Sehat (PHBS) pada Tatanan Rumah Tangga bahwa pada kelompok umur tua $\geq 30$ tahun lebih banyak menerapkan Perilaku Hidup Bersih dan Sehat (PHBS) yaitu 12 responden $(65,2 \%)$, dibandingkan dengan kelompok umur muda $\leq 30$ tahun yaitu 8 responden $(6,6 \%)$.

Hasil uji statistik menunjukan $P$-value hubungan antara umur dengan penerapan PHBS rumah tangga adalah 1,000. kesimpulannya bahwa tidak ada hubungan yang signifikan antara umur responden dengan penerapan Perilaku Hidup Bersih dan Sehat (PHBS) pada Tatanan Rumah Tangga di Pulau Lancang. Berarti tidak ada hubungan antara umur responden yang muda $<30$ tahun dengan umur responden yang tua $\geq 30$ tahun terhadap penerapan Perilaku Hidup Bersih dan Sehat (PHBS) pada Tatanan Rumah Tangga di Pulau Lancang.

Menurut Hurlock (2002) umur adalah usia seseorang yang dihitung sejak lahir sampai dengan batas terakhir masa hidupnya. Semakin cukup umur, tingkat kematangan dan kekuatan seseorang akan lebih matang dalam berfikir dan bekerja. Dari segi kepercayaan masyarakat, seseorang yang lebih dewasa akan lebih dipercaya dari orang yang belum cukup kedewasaanya. Hal ini sebagai akibat dari pengalaman dan kematangan jiwanya.

Hasil ini sesuai dengan penelitian Annisa Restiyani (2017) tentang faktor-faktor yang berhubungan PHBS Rumah Tangga di Cikarang, menunjukan bahwa tidak ada hubungan yang signifikan antara umur responden dengan lingkungan fisik rumah. Sehingga hasil ini menunjukan bahwa umur responden baik yang muda maupun yang tua sama-sama bisa menerapkan Perilaku Hidup Bersih dan Sehat (PHBS) pada Tatanan Rumah Tangga.

Hal ini dapat disimpulkan tidak adanya hubungan yang signifikan atau bermakna antara umur dengan penerapan PHBS Rumah Tangga di karenakan tidak ada pengaruh umur atau usia untuk bisa dapat melakukan penerapan PHBS.

\section{Pendidikan}

Dari hasil penelitian di Pulau Lancang tentang penerapan Perilaku Hidup Bersih dan Sehat (PHBS) menunjukan bahwa responden yang berpendidikan rendah lebih banyak menerapkan Perilaku Hidup Bersih dan Sehat (PHBS) yaitu 13 responden $(11,4 \%)$, dibandingkan dengan responden yang berpendidikan tinggi yaitu 7 responden $(8,6 \%)$. Hasil uji statistik menunjukan $P$-value hubungan antara pendidikan dengan penerapan PHBS rumah tangga adalah 0,318. kesimpulannya bahwa tidakada hubungan yang signifikan antara pendidikan responden dengan penerapan Perilaku Hidup Bersih dan Sehat (PHBS) pada Tatanan Rumah Tangga di Pulau Lancang.Sehingga hasil ini menunjukkan bahwa pendidikan responden baik rendah maupun tinggi tidak akan mempengaruhi pengetehaun masyarakat untuk hidup bersih dan sehat. 
Cumming dkk (Azwar, 2007), mengemukakan bahwa pendidikan sebagai suatu proses atau kegiatan untuk mengembangkan kepribadian dan kemampuan individu atau masyarakat. Ini berarti bahwa pendidikan adalah suatu pembentukan watak yaitu perilaku disertai kemampuan dalam bentuk kecerdasan, pengetahuan, dan keterampilan.

Pendidikan berarti bimbingan yang diberikan oleh seseorang terhadap perkembangan orang lain menuju kearah suatu cita-cita tertentu. Jadi dapat dikatakan bahwa pendidikan itu menuntun manusia berbuat dan mengisi kehidupannya mencapai keselamatan/kebahagian. Pendidikan diperlukan untuk mendapatkan informasi atau hal-hal yang menjungjung kesehatan, sehingga dapat meningkatkan kualitas hidup. (Nursalam, 2001). Tingkat pendidikan sangat berpengaruh terhadap perubahan sikap dan perilaku hidup sehat, tingkat pendidikan yang lebih tinggi akan memudahkan seseorang atau masyarakat untuk menyerap informasi dan mengimplementasikannya dalam perilaku dan gaya hidup sehari-hari, khususnya dalam hal pemenuhan kriteria rumah sehat (Wdya Karya Nasional, 2004 dalam Lestari, 2005).

Kepala keluarga punya andil besar dalam pencegahan penyakit. Pada kelompok kepala keluarga yang berpendidikan tinggi, dan punya penghasilan yang lebih baik, akan mempunyai kemampuan ekonomi untuk memfasilitasi kebutuhan keluarganya, khususnya dibidang kesehatan. Mosles dan Chen (1984) dalam Irvani (2001). Diasumsikan, dengan makin tingginya tingkat pendidikan kepala keluarga maka akan memudahkan dalam penyampaian informasi tentang kesehatan yang akan memperbesar kesempatan untuk hidup sehat bersama seluruh keluarganya.

Begitu juga dengan penelitian Novita Retno Hapsari (2010) tentang fakto-faktor yang berhubungan dengan Perilaku Hidup Bersih dan Sehat (PHBS) pada Rumah Tangga di Desa Tunggulsari Kecamatan Brangsong Kabupaten Kendal menunjukkan tidak ada hubungan yang signifikan antara tingkat pendidikan dengan praktik ibu rumah tangga tentang PHBS.

Tetapi hal ini tidak sejalan dengan penelitian Khairunnisa (2014) tentang gambaran Perilaku Hidup Bersih dan Sehat (PHBS) Tatanan Rumah Tangga di Kota Depok, menunjukkan bahwa adanya hububungan yang signifikan antara pendidikan dengan Perilaku Hidup Bersih dan Sehat (PHBS) Tatanan Rumah Tangga.

Kesimpulan dari penelitian bahwa pendidikan tidak berpengeruh dengan penerapan PHBS Rumah Tangga karena dari hasil survey dan pengisian kuesioner responden yang berpididikan rendah mengetahui PHBS sedangkan sebaliknya yang berpendidikan tidak belum tentu mengetahui PHBS.

\section{Pengetahuan}

Dari hasil penelitian di Pulau Lancang tentang penerapan Perilaku Hidup Bersih dan Sehat (PHBS) pada Tatanan Rumah Tangga menunjukan bahwa responden yang tingkat pengetahuannya tinggi lebih banyak menerapkan Perilaku Hidup Bersih dan Sehat (PHBS) yaitu sebanyak 14 responden (7,1\%) dibandingkan dengan responden yang tingkat pengetahuannya rendah yaitu 6 responden $(12,9 \%)$.

Hasil uji statistik menunjukan $P$-value hubungan antara pengetahuan dengan penerapan PHBS rumah tangga adalah 0,118 kesimpulannya bahwa tidak ada hubungan yang signifikan antara tingkat pengetahuan responden dengan penerapan Perilaku Hidup Bersih dan Sehat (PHBS) pada Tatanan Rumah Tangga di Pulau Lancang 
Pengetahuan adalah hasil dari tahu, yang terjadi setelah seseorang melakukan penginderaan melalui panca inderanya terhadap suatu objek yang tertentu. Pengetahuan merupakan akumulasi dari berbagai pengalaman untuk memecahkan suatu masalah. Sebagian besar dari pengetahuan manusia diperoleh melalui mata dan telinga, selanjutnya pengetahuan yang telah diperoleh akan mendasari seseorang dalam berperilaku. Perilaku yang didasari oleh pengetahuan biasanya akan lebih bertahan dari pada perilaku yang tidak didasari oleh pengetahuan. Pengetahuan ini dapat diperoleh dari pengalaman sendiri maupun orang lain. Notoatmodjo (1999) dalam Irvani (2001).

Pengetahuan adalah salah satu indikator yang memungkinkan seseorang untuk mempunyai rumah yang layak dan sehat. Pengetahuan juga salah satu domain penting terhadap perilaku seseorang. Perilaku dalam penelitian ini adalah mengenai perilaku yang mengarah pada penerapan Perilaku Hidup Bersih dan Sehat (PHBS).

Menurut Rogers dalam Notoatmodjo (2003), perilaku yang didasari oleh pengetahuan akan lebih baik dari pada perilaku yang tidak didasari oleh pengetahuan. Semakin tinggi tingkat pengetahuan seseorang maka semakin tahu tentang pentingnya Perilaku Hidup Bersih dan Sehat (PHBS).

Hasil ini sejalan pada penelitian Syafni Meilisa tentang hubungan pengetahuan dan sikap keluarga tentang PHBS dengan penerapan PHBS tatanan rumah tangga, munujukkan bahwa tidak adanya hubungan yang signifikan antara pengetahuan dengan penerapan PHBS di tatanan rumah tangga.

Tetapi tidak sejalan pada penelitian Siska Damaiyanti (2014) tentang hubungan pengetahuan ibu rumah tangga dengan Perilaku Hidup Bersih dan Sehat (PHBS) di Kelurahan Laing wilayah kerja Puskesmas Nan Balimo Kecamatan Tanjung Harapan Kota Solok, menunjukan bahwa pengetahuan responden mempunyai hubungan yang signifikan dengan penerapan Perilaku Hidup Bersih dan Sehat (PHBS) pada Tatanan Rumah Tangga.

Berdasarkan hasil penelitian ini, pengetahuan tidak memiliki hubungan yang signifikan dengan penerapan PHBS. Hal ini berlawanan dengan teori Green (1980) yang mengklasifikasikan pengetahuan ke dalam faktor predisposisi atau pemudah seseorang untuk berperilaku. Seharusnya pengetahuan tinggi dapat mempermudah seseorang untuk menerapkan perilaku hidup bersih dan sehat. Akan tetapi, dalam penelitian ini meskipun proporsi responden dengan pengetahuan tinggi lebih banyak daripada yang berpengetahuan rendah hal tersebut belum dapat menjamin seseorang untuk ber-PHBS.

\section{Sikap}

Dari hasil penelitian di Pulau Lancang tentang penerapan Perilaku Hidup Bersih dan Sehat (PHBS) pada Tatanan Rumah Tangga menunjukan bahwa responden yang bersikap baik lebih banyak menerapkan Perilaku Hidup Bersih dan Sehat (PHBS) yaitu 17 responden (10,3\%), dibandingkan dengan responden yang bersikap kurang baik yaitu 3 responden $(9,7 \%)$.

Kemudian hasil uji statistik menunjukanP-value hubungan antara sikap dengan penerapan PHBS rumah tangga adalah 0,125 . Kesimpulannya adalah bahwa tidak ada hubungan yang signifikan antara sikap responden dengan penerapan Perilaku Hidup Bersih dan Sehat (PHBS) pada Tatanan Rumah Tangga di Pulau Lancang. 
Menurut Soetarno (1994)sikap adalah pandangan atau perasaan yang disertai kecenderungan untuk bertindak terhadap obyek tertentu. Sikap senantiasa diarahkan kepada sesuatu artinya tidak ada sikap tanpa obyek. Sikap diarahkan kepada benda-benda, orang, peritiwa, pandangan, lembaga, norma dan lain-lain.

Hasil ini sejalan dengan penelitian Tri Hesti Oktaviani (2013) tentang faktor-faktor yang berhubungan dengan Perilaku Hidup Bersih dan Sehat (PHBS) pada Tatanan Rumah Tangga, munujukkan bahwa tidak adanya hubungan yang signifikan antara sikap dengan penerapan Perilku Hidup Bersih dan Sehat (PHBS) di Tatanan Rumah Tangga. Tetapi hasil ini tidak sejalan dengan penelitian Heni Trisnowati (2017) tentang hubungan pengetahuan dan sikap terhadap PHBS rumah tangga di Dusun Karangnongko Yogyakarta, menunjukkan bahwa adanyaa hubungan yang signifikan antara sikap dengan penerapan Perilaku Hidup Bersih dan Sehat (PHBS) pada Tatanan Rumah Tangga.

Berdasarkan hasil penelitian ini, sikap tidak memiliki hubungan yang signifikan dengan penerapan PHBS. Hal ini berlawanan dengan teori Green (1980) yang mengklasifikasikan sikap ke dalam faktor predisposisi atau pemudah seseorang untuk berperilaku. Seharusnya pengetahuan tinggi dapat mempermudah seseorang untuk menerapkan perilaku hidup bersih dan sehat. Akan tetapi, dalam penelitian ini meskipun proporsi responden dengan sikap positif lebih banyak daripada yang bersikap negatif hal tersebut belum dapat menjamin seseorang untuk ber-PHBS. Sesuai dengan yang di kemukakan Notoatmodjo (2010), bahwa sikap positif terhadap nilai-nilai kesehatan tidak selalu terwujud dalam suatu tindakan nyata. Dalam penelitian Mabun (2011), sikap tidak memiliki hubungan bermakna kemungkinan disebabkan karena variabel ketersediaan saran lebih mempengaruhi perilaku bersih dan sehat.

\section{Ketersediaan Sarana Prasarana}

Dari hasil penelitian di Pulau Lancang tentang penerapan Perilaku Hidup Bersih dan Sehat (PHBS) pada Tatanan Rumah Tangga menunjukan bahwa responden yang sarananya memadai lebih banyak menerapkan Perilaku Hidup Bersih dan Sehat (PHBS) yaitu 13 responden (12,6\%), dibandingkan dengan responden yang sarananya kurang memadai yaitu 7 responden $(7,4 \%)$.

Kemudian dari hasil uji bivariat di dapat $P$-value hubungan antara ketersediaan sarana prasarana dengan penerapan PHBS rumah tangga adalah 0,265. Kesimpulannya adalah tidak ada hubungan yang signifikan antara ketersediaan sarana prasarana terhadap penerapan PHBS rumah tangga.

Menurut Moenir (2010), sarana dan prasarana adalah merupakan seperangkat alat untuk digunakan dalam suatu proses kegiatan baik alat tersebut adalah merupakan peralatan pembantu maupun peralatan utama, yang keduanya berfungsi untuk mewujudkan tujuan yang hendak dicapai.

Sarana dan prasarana atau fasilitas merupakan faktor yang memungkinkan atau yang memfasilitasi perilaku atau tindakan kesehatan misalnya, Puskesmas, Posyandu, Rumah Sakit, tempat penampungan air, tempat penampungan sampah, tempat olahraga, dan sebagainya. Sebuah keluarga yang sudah tau masalah kesehatan, mengupayakan keluarga nya untuk menggunakan air bersih, buang air besar di WC, makan-makanan yang bergizi dan sebagainya. Tetapi apanila keluarga tersebut tidak mampu mengadakan fasilitas itu semua, maka dengan terpaksa buang air besar di kali/kebun, menggunakan air kali untuk keperluan sehari-hari, makan seadanya, dan sebagainya (Notoatnodjo, 2010). 
Hasil penelitian ini sejalan dengan penelitian Andriadi (2011) tentang 'faktor-Faktor Yang Berhubungan Dengan Perilaku Hidup Bersih dan Sehat Anak Remaja Kelas VII dan VIII di SMP 258 Kelurahan Cibubur Jakarta Timur', dari hasil analisis bivariat diketahui tidak ada hubungan yang signifikan antara ketersediaan sarana prasaran dengan penerapan PHBS. Tetapi hal ini tidak sejalan dengan hasil penelitian Nita Novianti (2014) tentang 'Faktor-Faktor Yang Berhubungan Dengan Penerapan Perilaku Hidup Bersih dan Sehat (PHBS) Rumah Tangga di Kelurahan Jatiasih, Bekasi', dari hasil analisis bivariat diketahui adanya hubungan yang signifikan antara ketersediaan sarana prasarana dengan penerapan PHBS.

\section{KESIMPULAN DAN REKOMENDASI}

Berdasarkan hasil penelitian tentang penerapan Perilaku Hidup Bersih dan Sehat (PHBS) Rumah Tangga di Pulau Lancang, maka dapat disimpulkan sebagai berikut:

1. Sebanyak 20 responden $(28,6 \%)$ yang menerapkan Perilaku Hidup Bersih dan Sehat (PHBS) sedangkan rumah yang

2. tidak menerapkan lebih banyak yaitu sebanyak 50 responden $(71,4 \%)$.

3. Variabel independen (umur, pendidikan, pengetahuan, sikapn dan ketersediaan sarana)

a. Responden yang umurnya tua $\geq 30$ tahun lebih banyak menerapkan Perilaku Hidup Bersih dan Sehat (PHBS) yaitu sebanyak 12 responden $(13,4 \%)$, dibandingkan dengan responden yang berumur muda $\leq$ 30 tahun yaitu sebanyak 8 responden $(6,6 \%)$.

b. Responden yang berpendidikan rendah lebih banyak menerapkan Perilaku Hidup Bersih dan Sehat (PHBS) yaitu sebanyak 13 responden $(11,4 \%)$, dibandingkan dengan responden yang berpendidikan tinggi sebanyak 7 responden $(8,6 \%)$.

c. Responden yang pengetahuannya tinggi lebih banyak menerapkan Perilaku Hidup Bersih dan Sehat (PHBS) yaitu sebanyak 14 responden $(7,1 \%)$, dibandingkan dengan responden yang berpendidikan rendah 6 responden $(12,9 \%)$.

d. Responden yang sikapnya baik lebih banyak menerapkan Perilaku Hidup Bersih dan Sehat (PHBS) yaitu sebanyak 17 responden (10,3\%), dibandingkan dengan responden yang sikapnya kurang baik yaitu 3 responden $(9,7 \%)$.

e. Responden yang ketersediaan sarana prasarananya memadai baik lebih banyak menerapkan Perilaku Hidup Bersih dan Sehat (PHBS) yaitu sebanyak 13 responden $(12,6 \%)$ dibandingkan dengan responden yang ketersediaan sarananya kurang memadai yaitu 7 reponden $(7,4 \%)$.

1. Variabel independen (umur, pendidkan, pengetahuan, sikap dan ketersediaan sarana prasarana). Dari hasil uji statistik tidak ada hubungan yang signifikan antara penerapan Perilaku Hidup Bersih dan Sehat (PHBS) pada Tatanan Rumah Tangga dengan umur $(P$-Value $=1,000)$, pendidkan $(P$-Value $=0,318)$, pengetahuan $(P$-Value $=0,118)$, sikap $(P$-Value $=0,125)$ dan ketersediaan saran prasarana $(P$-Value $=0,265)$. 
Berdasarkan kesimpulan dan pembahasan hasil penelitian tentang penerapan Perilaku Hidup Bersih dan Sehat

(PHBS) Tangga di Pulau Lancang, maka dapat disarankan beberapa hal berikut ini:

1. Bagi pemerintah (Kelurahan) perlu berperan aktif dalam memotivasi warga masyarakatnya untuk meningkatkan sanitasi rumah di Kelurahan Pulau Lancang.

2. Bagi petugas kesehatan (sanitarian) lebih pro aktif turun ke lapangan untuk memberi pendidikan kesehatan (penyuluhan) kepada masyarakat dan menyadarkan masyarakat bahwa Perilaku Hidup Bersih dan Sehat (PHBS) sangat penting.

3. Membentuk kaderisasi di lingkungan masyarakat tersebut sehingga dapat memfasilitasi terhadap masyarakat yang kurang memahami tentang manfaat berperilaku hidup sehat.

4. Bagi masyarakat Pulau Lancang lakukanlah semaksimal mungkin untuk menerapkan Perilaku Hidup Bersih dan Sehat (PHBS).

\section{REFERENSI}

1. Kementerian Kesehatan. Peraturan Menteri Kesehatan Republik Indonesia Nomor; 2269/MENKES/PER/IX/2011. (2011). Pedoman Pembinaan Perilaku Hidup Bersih dan Sehat (PHBS) Pada Tatanan Rumah Tangga.

2. Profil Puskesmas Kelurahan Pulau Pari Kecamatan Kepulauan Seribu Selatan (Tidak dipublikasikan)

3. Profil Kelurahan Pulau Pari Kecamatan Kepulauan Seribu Selatan (Tidak dipublikasikan)

4. Bagian Promosi Kesehatan dan Ilmu Perilaku Fakultas Kesehatan Masyarakat 2015. Bab I Pendahuluan

Laporan Mahasiswa Universitas Jember. [online]

http://repository.unej.ac.id/bitstream/handle/123456789/723501/112`1110101018--

Prita\%20Eka\%20Pratiwi-1-78.pdf?sequence=1 di peroleh juni 2018

5. Novita Retno Hapsari. Analisis Faktor Yang Berhubungan Dengan Praktik Ibu Rumah Tangga Tentang $\mathrm{t}$ Perilaku Hidup Bersih dan Sehat (PHBS) di Desa Tunggusari Kecamatan Brangsong Kabupaten Kendal Tahun 2010. [online] http://lib.unnes.ac.id/5051/1/6305_A.pdf di peroleh juni 2018

6. Siska Damaiyanti, Crisni Hardyanti. Hubungan Pengetahuan Ibu Rumah Tangga dan Peran Kader Dengan Perilaku Hidup Bersih dan Sehat (PHBS) Dalam Rumah Tangga di Kelurahan Laing Wilayah Kerja Puskesmas Nan Balimo Kecamatan Tanjung Harapan Kota Solok Tahun 2014. [online] https://anzdoc.com/siska-damaiyanti-1-crisni-hardyanti-2.html di peroleh juni 2018

7. Sarimawati Sitohang. Hubungan PHBS Dengan Kejadian Diare Pada Balita di Wilayah Kerja Puskesmas $\begin{array}{llll}\text { Hutabaginda } & \text { Kecamatan } & \text { Terutung } & \text { Tahun }\end{array}$ http://repositori.usu.ac.id/bitstream/handle/123456789/737/147032122.pdf?sequence=1\&isAllowed=y di peroleh juni 2018.

8. Annisa Restiyani. Faktor-Faktor Yang Berhubungan PHBS Rumah Tangga di Cikarang(2017).[online] https://ejournal3.undip.ac.id/index.php/jkm/article/view/19222 di peroleh juni 2018

9. Notoatmodjo S. Pendidikan Promosi dan Perilaku Kesehatan. Jakarta: 
10. Universitas Indonesia Fakultas Kesehatan Masyarakat; 2000.

11. Badan Penelitian dan Pengembangan Kesehatan Kementrian Kesehatan Republik

12. Indonesia. Riset Kesehatan Dasar. Jakarta2013.

13. Notoatmodjo S. Pendidikan Promosi dan Perilaku Kesehatan. Jakarta:

14. Universitas Indonesia Fakultas Kesehatan Masyarakat; 2000.

15. Windari S. Faktor-faktor yang berhubungan dengan pelaksanaan perilaku hidup

16. bersih dan sehat pada tatanan rumah tangga di kelurahan parak laweh pulau airpadang: Universitas Baiturahmah; 2005.

17. Amalia I. 2009. Hubungan Antara Pendidikan, Pendapatan Dan Perilaku Hidup Bersih Dan Sehat (Phbs) Pada Pedagang Hidangan Istimewa Kampung (Hik) Di Pasar Kliwon Dan Jebres Kota Surakarta. Surakarta.

18. Andriadi, Wisnu. 2011. Faktor-Faktor yang Berhubungan dengan Perilaku Hidup Bersih dan Sehat Anak Remaja Kelas VII dan VIII di SMP 258 Kelurahan Cibubur Jakarta Timur. Jakarta, Universitas Pembangunan Nasional. Skripsi

19. Nita Novianti. 2014. Faktor-Faktor yang Berhubungan dengan Penerapan Perilaku Hidup Bersih dan Sehat (PHBS) Rumah Tangga di Kelurahan Jatiasih, Bekasi. Universitas MH Thamrin. Skripsi

20. Kemenkes RI. 2009. Undang-Undang No 39 tahun 2009 tentang Kesehatan. Jakarta: Kemenkes RI

21. Kemenkes RI. 2010. Buletin Jendela Epidemiologi : Demam Berdarah Dengue. Jakarta : Pusat Data dan Surveilans Epidemiologi

22. Kemenkes RI. 2010. "Keluarga Sehat, Investasi Bangsa”. Diakses pada 27 Juli 2018 http://www.depkes.go.id

23. Kemenkes 2010. Riset Kesehatan Dasar (RISKESDAS) 2007. Jakarta : Badan Penelitian dan Pengembangan Kesehatan

24. http://pulauseribu.jakarta.go.id/web/v3/?p=berita\&id=5496

25. Heni Trisnowati (2017) Hubungan pengetahuan dan sikap terhadap PHBS rumah tangga di Dusun Karangnongko Yogyakarta, Skripsi

26. Hesti Oktaviani (2013) faktor-faktor yang berhubungan dengan Perilaku Hidup Bersih dan Sehat (PHBS) pada Tatanan Rumah Tangga. Skripsi 